\title{
THE ANTHROPOGENIC TOURISM POTENTIAL AND ITS CAPITALIZATION POSSIBILITIES IN IARA-HĂȘDATE BASIN
}

\author{
CIPRIAN MOLDOVAN ${ }^{1}$, ŞTEFAN DEZSI ${ }^{1}$, RAULARIAN RUSU1, \\ TITUS MAN ${ }^{1}$, EUGEN BOGDAN DOLEAN ${ }^{1}$
}

\begin{abstract}
The Anthropogenic Tourism Potential and Its Capitalization Possibilities in Iara-Hășdate Basin. The paper deals with the anthropogenic tourism resources of Iara-Hășdate Basin, which are the result of the combining effect of history, development of human civilization and typology and traditions of ethnic groups inhabiting the basin. The result is a unique cultural heritage belonging to both material and spiritual legacy, with visible attractive products for tourism materialized mostly in architecture, clothing, customs, music and gastronomy. The historical evolution of the area is reflected not only by culture, traditions and attitudes of the people towards lifetime events, but also by the relatively high number of tourism attractions from different historical periods, generating iconic architectural, historical and religious landmarks. Considering the complexity of tourism resources available in Iara-Hășdate Basin, there are multiple types of tourism offered by the area. Existing natural conditions favor various forms of recreational mountain tourism from traditional winter leisure tourism, hiking and hunting tourism to more extreme ones like mountain climbing, caving and extreme tourism. The rich historical cultural heritage of the studied area offers very good premises for the development of various cultural tourism forms, mostly rural and religious tourism. The results of tourism resources assessment can be used to coordinate tourism development strategies for a superior endorsement and to better prioritize tourism related policies with a focus on economic development, land use management, territorial identity and environmental quality.
\end{abstract}

Keywords: anthropogenic tourist resources, types and forms of tourism, rural tourism, cultural tourism, Iara-Hășdate Basin.

1 "Babeș-Bolyai" University, Faculty of Geography, 5-7 Clinicilor Street, Cluj-Napoca, Romania, e-mails: ciprian.moldovan@ubbcluj.ro, stefan.dezsi@ubbcluj.ro, raularian.rusu@ubbcluj.ro, titus.man@ubbcluj.ro,dolean_eugen@yahoo.com 


\section{INTRODUCTION}

The tourism resources group the totality of attractive elements in a territory that may be capitalized by means of tourism, regardless of their natural or anthropogenic origin and the relations that exist between them. They lie at the basis of the emergence and development of tourism, representing its "raw material". At the same time, due to their qualitative, quantitative and locational features and as the result of inserting structurally, physiognomically, dimensionally and functionally adapted tourism plans, they may determine the establishment of tourism convergent flows that are differentiated in terms of size, intensity and diversity, and to determine the option for the type of practiced tourism, as well as the intrinsic value of tourism consumption and therefore the economic efficiency of the associated tourism act (Cocean and Dezsi, 2009, Snak, 1976; Glăvan, 2000; Cândea and Simon, 2006).

Complementary to the tourism natural heritage of the area of reference, which constituted the object of a previous study (Moldovan et al, 2017), the anthropogenic heritage represents, in its turn, an integral part of the primary or potential tourism supply, as both attractive categories form the fundamental factors or the essential motivation for the emergence and development of tourism. The anthropogenic heritage is the consequence of a continuous process of multiplication and diversification, resulting from the demographic increase which stimulated the ascendant-spiraling evolution of the humanity, its material civilization and spiritual culture. In this context, apart from the attractive elements belonging to the natural environment, tourism massively appeals to a series of attractive elements (in different forms of expression) coming out from the creativity and spirituality proper to the human individual (Cocean and Dezsi, 2005, Cocean and Dezsi, 2009).

Starting from the premise that "the anthropogenic potential is the one which lays at the basis of the functional system of tourism", Muntele and Iaţu (2003, p. 89, apud Cazes, 1992) include within the category of anthropogenic factors both the primary elements representing the cultural-artistic heritage and those created for leisure, i.e. the secondary elements generated by tourism activity. In our opinion, the latter ones are elements of the tourism infrastructure or the technical-material resources, considered as components of the secondary supply, which represent the decisive factor of establishing tourism as a concrete spatial phenomenon, as a result of the transformation of attractive elements into a tourism product and the provision of the comfort needed for the development of the tourism act in optimal conditions (Cocean and Dezsi, 2009). 
Among the many existing works in the literature looking to assess the structure of the anthropogenic tourism potential, one considers the complex classification of its elements performed by Glăvan (2000). He grouped them into three categories of potential: the cultural-historical one, the technicaleconomic one and the socio-demographic one. In their turn, these are made up by 18 components, from historical monuments and folk events to tourism villages, economic units, social institutions and population. One also takes into account the complex classification of Minciu (2004), who subordinates 12 subcategories of anthropogenic attractions to homogeneous groups of sociodemographic potential, technical-economic aspects, institutions and events, and cultural-artistic attractions. A classification that has a lower degree of complexity and is therefore less relevant has been performed by Cândea and Şimon (2006), who assimilate the anthropogenic heritage to the set of cultural and socio-economic components of the social environment. The approach of Ielenicz and Comănescu (2013) involves a classification according to the historical features, the architectural, art or religious importance, the nationalfolkloric characteristics, as well as the economic, artistic or memorial features. In this context, one also considers the proposals made by Ciangă (1997 and 2007), related strictly to the cultural and historical features of the anthropogenic potential, approached in an organized manner by categories, subcategories and elements.

In our opinion, a more efficient and functional approach of structuring the anthropogenic attractive resources has been proposed by Mac (1992) and used by Cocean (1996), Cocean and Dezsi (2009) and partly by Negut (2003). It integrates historical buildings, religious buildings, cultural buildings, economic buildings that have a tourism function, human activities that have a tourism function and ethnographic tourism resources. This approach has been also accepted by other authors, in different papers (Răcăşan, 2014; Răcăşan et al., 2016; Răcăşan, 2015; Dezsi, 2006 etc.). In this context, the assessment and classification of the anthropogenic attractive resources performed in this paper has adapted to the configuration of the anthropogenic heritage in the study area, whose structure was assessed according to the typology of analyzed objectives.

\section{METHODOLOGY}

This paper approaches and assesses the attractive features of the tourism resources belonging to the anthropogenic heritage in the study area. The research methodology included the review of bibliography, mainly the monographies 
presenting communes or villages located in the study area (Bodea, 2009, Cinezan, 2011, Copilu Cheatra, 1989, Gergely, 2002, Gergely and Luca, 2004, Lăzărescu, 2006, Luca, 2007, Surd, 2013, Vana, 2003), other monographic studies and research projects focused on Cluj County as a whole (Buta, Idu and Edroiu,1980, Morariu and Savu,1970, Negucioiu, Teodor and Edroiu, 1980), plans and development strategies also referencing the county (Pop Gr. P., 2007, Pop, I.A., Danciu, Cocean and Luțaş 2008), tourist guidebooks (Mititean and Kadar, 2006), the Romanian Encyclopedia (http://enciclopediaromanieiro/ wiki/Portul_popular_din_Transilvania), cartographic documents (the Romanian Ethnographic Atlas: Ghinoiu, 2003 a, b, 2005a,b, 2011), as well as online information available on the websites of specialized institutions, such as the

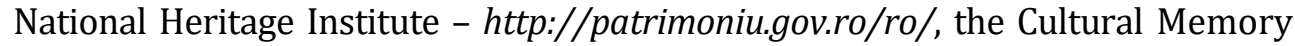
Institute - http://www.cimec.ro/Monumente/LacaseCult/default_ro.htm, Cluj County Council - http://www.cjcluj.ro/judet/, http://www.cjcluj.ro/ etc., corroborated with the authors' field observations.

\section{THE ANTHROPOGENIC TOURISM POTENTIAL}

The analysed area is an integral part of a region that has a material and spiritual culture well within the established national heritage. The interference and exchange with the neighbouring territorial systems of different ranks and spatial extensions may lead to original solutions for its better capitalization by means of tourist activities. The anthropogenic tourism heritage has an important weight in the structure of the tourism potential of the analysed area and is harmoniously complementary to the natural tourism potential. The adapted tourism strategies may determine varied types and forms of tourism and the polarisation of tourism flows oriented, sized and structured according to them.

In terms of variety and value, the anthropogenic tourist resources of the analysed area are directly linked to the long evolution of human civilization and the interferences between the diverse ethnical groups characteristic for Transylvania (and implicitly for Cluj County and Iara-Hășdate Basin) and their specific heritage, whose unique mark resulted after centuries of evolution and is found in the material and spiritual culture, represented by the architecture and manner of organisation of villages and households, traditions, customs, clothing, music, gastronomy, mentality. 
The specific conditions of the historical, economic, social and political development and evolution of the analysed area, determined by the geographical position and the physical-geographical conditions, which allowed the insertion and active adaptation of the human element, have had a peculiar reflection in the culture and traditions of the people and their system of values. This has not led to a loss or dilution of their particular social, cultural or economic characteristics, well individualised as a result of a centuries-long evolution integrated in the Transylvanian regional culture.

As a consequence of this specific situation, one remarks a number of typologies, each having a different weight within the villages of the analysed basin. Because of this, the villages inhabited by a Hungarian population should be inserted in the functional tourism circuits, therefore contributing to a higher variety of the tourism supply, meeting the demands and needs of new market segments. This also makes sense as some of the Hungarian celebrations (the winter or Easter holidays) have a different schedule and sometimes take place in a different period than the ones of the majority Orthodox Romanian population.

In this context, the analysed territory has a rich and complex cultural heritage, whose ancient historical tradition is proven by archaeological discoveries and the high number of historical, architectural and religious monuments belonging to different historical periods.

All these result in the opportunity to provide a relatively diverse and complementary (structurally, physiognomically and functionally) tourism supply which would allow, in the future, the establishment of converging tourist flows able to capitalize it at higher levels of social and economic efficiency.

2.1. The cultural and historical tourism heritage represents the most valuable component of the entire anthropogenic heritage, as it is the result of a long and eventful history. It belongs to human communities which contributed to the creation of one of the most varied and valuable multicultural heritage, determined by different national and religious groups that were involved throughout the centuries in the establishment of this complex set, which has a unique personality.

The spatial structure of Iara-Hășdate Basin, corroborated with the peculiarities of the other elements belonging to the natural environment (climate, drainage network, vegetation and fauna), favorized an ancient population settlement in this area, proven by archaeological artifacts, that attest the succession of civilisations and implicitly the continuity of population and intense habitation across this territory, as well as a diversified range of activities capitalizing the natural environment and its resources. 


\section{Archaeological artifacts}

A number of archaeological sites are included on the list of historical monuments in the analysed area. They cover all historical periods from the early Stone Age to the end of the Middle Ages.

The list of historical monuments includes a selection of the best known and most researched archaeological sites. The most representative ones are located on the territory of the following villages: Liteni (the sites known as „Piatra Mare" and "Cetate"), Petreștii de Jos ("Crucea Cheii" site), Tureni (the sites called "La furci", "Svona" and "Dealul”), Mărtinești ("Dealul Bisericii”), Micești ("Valea Micuşului") and Petreştii de Sus ("Valea Sărăcăzii" and "Terasa" near the school and the parish house).

Different types of artifacts (villages, cairns, necropolises etc) belonging to prehistorical period have been documented in several villages. The most representative ones are located in Iara, Petreştii de Jos, Sălicea, Săvădisla, Mărtinești, Tureni, Vlaha and Petreștii de Jos.

The Neolithic (or the New Stone Age, around 6000-3000 BC), characterised by the emergence of agriculture and pottery, is represented by the sites located in Petreștii de Sus (the settlement at the site called "Terasa" near the school and the parish house) and Petreştii de Jos (the settlement at the site called "Crucea Cheii").

In its turn, the Bronze Age (the first Metal Age, around 3000-1000 BC) is attested in villages like Liteni, Petreştii de Jos, Tureni, Petreștii de Sus and Sălicea.

The Early Iron Age (around 800-450 BC), also called Hallstatt Age, is represented by large-sized settlements, fortified with walls made of earth and stockades, such as those at Micești and Tureni.

The Late Iron Age (also called La Tène) corresponds to the period of the Dacian Kingdom and it is represented by many Dacian, Celtic and Scythian settlements. The fortified settlements at Liteni, Tureni and Sălicea are important vestiges of the period.

The Roman period ( $2^{\text {nd }}$ and $3^{\text {rd }}$ centuries $\mathrm{AD}$ ) represents the period of the organisation of the Dacian Province within the Roman Empire. It is well represented by many artifacts belonging to the Roman civilisation, especially village and villas (farms located outside towns). The high human density during the Roman period is indicated by the high number of discoveries, located in several sites (Iara, Mărtineşti, Miceşti, Petreștii de Jos, Petreştii de Sus). 
The historical periods after the Roman age are also represented across the analysed territory. Artifacts belonging to the age of migrations (4th to $9^{\text {th }}$ centuries) have been discovered at Săvădisla, Petreștii de Jos, Petreștii de Sus, Tureni.

The Early Middle Ages ( $9^{\text {th }}$ to $12^{\text {th }}$ centuries) is represented by several fortresses, like those at Liteni, Săvădisla (11 th to $17^{\text {th }}$ centuries) and Lita, located near Săcel, Băișoara commune (13 $13^{\text {th }}$ to $15^{\text {th }}$ centuries), which was also the Cluj County seat for a period, moved here because of the Mongol invasion in 1241.

They are in a precarious state of conservation, due to the long period passed since their building and the impact of the social and historical events. Their age and derelict state constitute major barriers in transforming them into tourist attractions of their own. However, the archaeological artifacts exhumed and preserved on site, as well as those taken and stored in museums, present a peculiar interest only for a limited category of scientists, very small in terms of numbers and therefore economically irrelevant.

Constant advertising, properly directed to specific segments of the tourist demand, together with the creation of access ways, modern parking lots, as well as minimal tourism facilities, would enhance the emotional impact on the collective conscience and the interest derived from the symbolic value of their cumulated features. In this context, there would be definite positive effects of their integration in the functional tourist circuits.

During the medieval and modern period, several manors have been built by the nobility on their domains. The most representative ones are those belonging to the Teleki, Beldi and Kemeny families, all built during the 19 century in Iara, as well as Veres Castle (in Pruniș, village belonging to Ciurila commune, built in the $18^{\text {th }}-19^{\text {th }}$ centuries) and Mikes Castle in Săvădisla, built during the $19^{\text {th }}$ century.

\section{Religious tourist attractions}

The religious buildings (churches and monasteries) are anthropogenic tourist attractions that are representative for all the communities within the analysed territory, due to their historical and cultural importance and implicitly they are potential tourist attractions. Churches and monasteries represent remarkable technical and artistic achievements, which have a high symbolic value and are significant because of their size, iconography and collections of religious objects, but also due to their architecture and style, according to the historical period in which they were built. 
Surduc wooden church

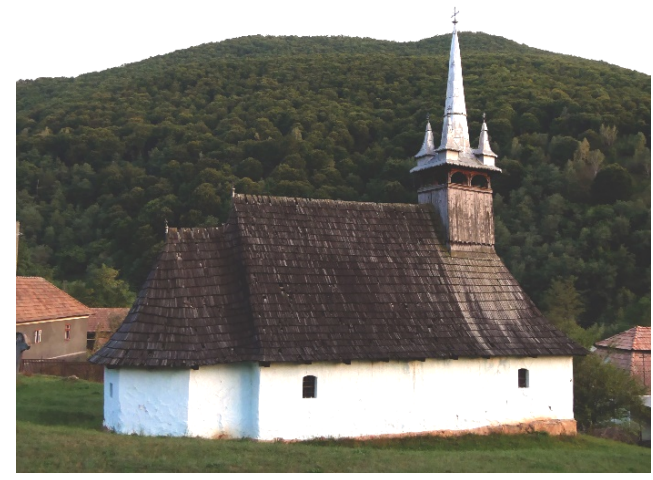

Pădureni wooden church

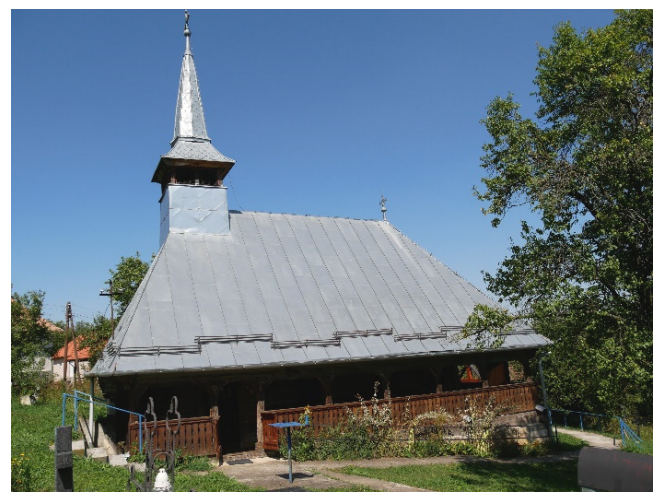

Finișel wooden church

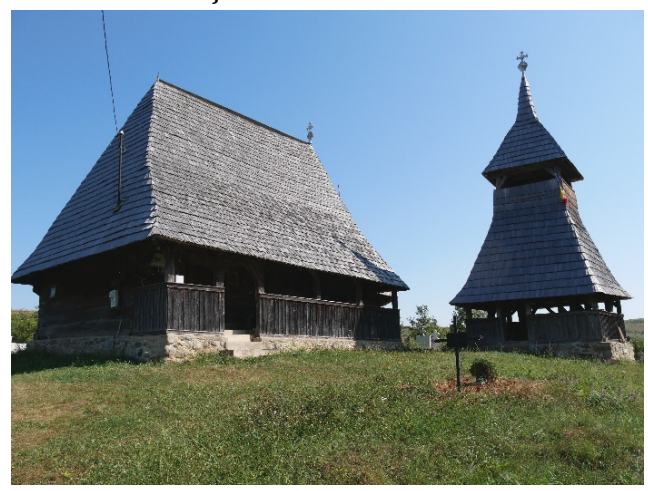

„Pious Paraskeva” wooden church

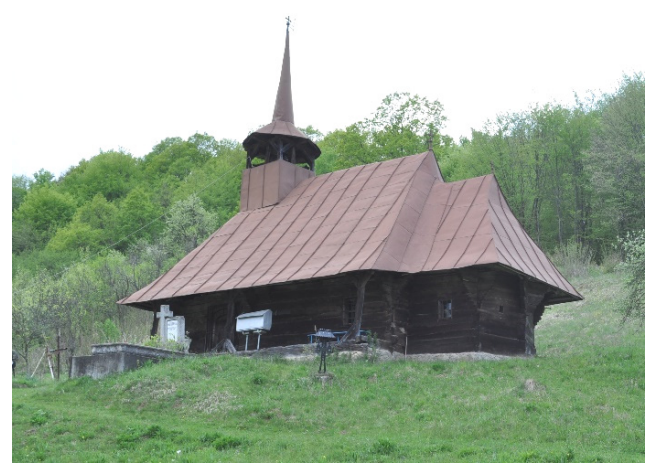

Fig. 1. Some of the most important wooden churches in Iara-Hășdate basin

\section{The attractive potential of the wooden churches}

Cluj County, together with Maramureş, Sălaj, Bihor and Alba counties, is well-known for the high number of religious buildings made of wood. There are 84 wooden churches in Cluj County, although only 14 of them are classified as monuments of national interest. Their importance for tourism comes from:

- Age - most wooden churches across Cluj County date from the $18^{\text {th }}$ and $19^{\text {th }}$ centuries;

- Architecture -they usually have three rooms which lie longitudinally, separated by transversal walls: narthex, nave and chancel. The tower, campanile and apse are architectural elements that are characteristic for wooden churches. 
- The conservation of valuable paintings - most often those which represent scenes from the life of Jesus, Virgin Mary, the Evangelists, the prophets, as well as the paintings "The Wise Virgins" and "The Mad Virgins".

- Icons on glass.

Many of these churches have suffered structural damages, not just because of usual wear and tear, but also due to certain historical events which affected them partially or totally.

Among the wooden churches located in the study area, one remarks the age and the historical, cultural and artistic values of "Saint Archangels Michael and Gabriel" Church in Măgura Ierii village (Iara commune), built in 1783, the church in Pădureni (Ciurila commune), built in 1750, the church in Finișel (Săvădisla commune), built in 1758, which also includes a bell tower built in the $18^{\text {th }}$ or $19^{\text {th }}$ century, the church in Surduc (Iara commune), attested in the $18^{\text {th }}$ century, and the "Pious Paraskeva" Church in Stolna (Săvădisla commune), built in 1730 .

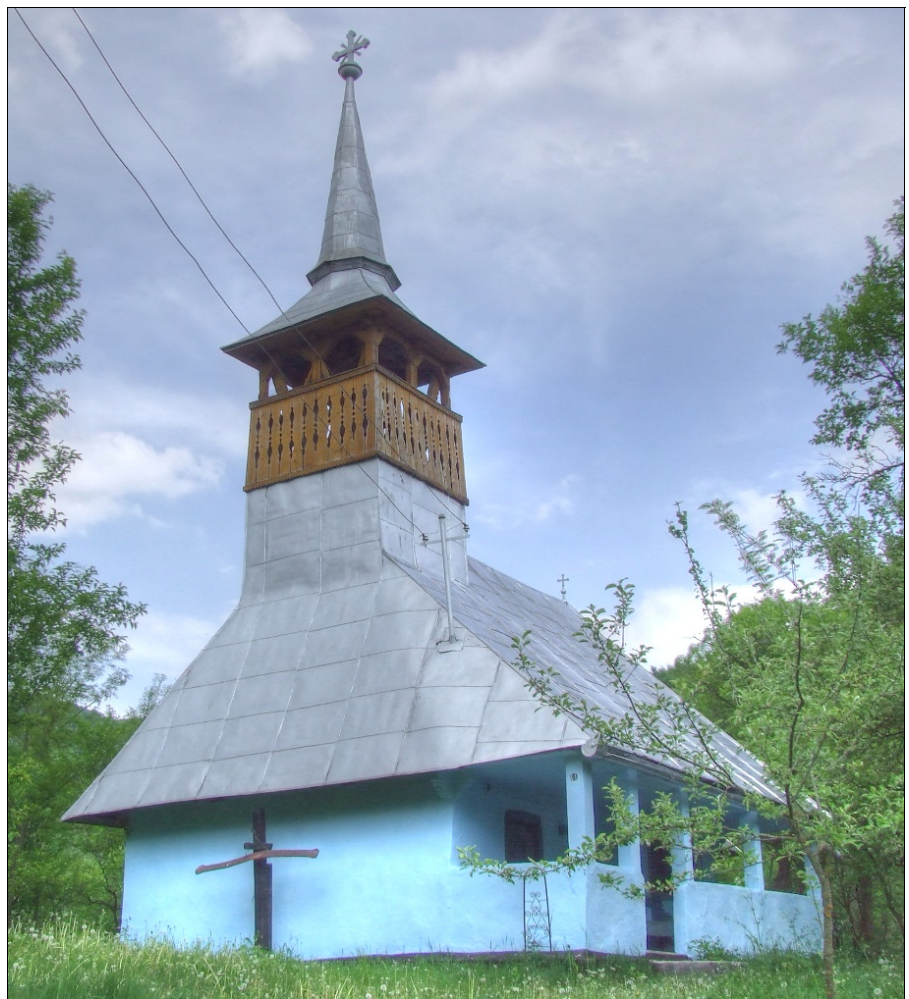

Fig. 2. „Saint Archangels Michael and Gabriel” Church (Măgura Ierii village, Iara commune) 


\section{The attractive potential of the stone churches}

The unfavourable political and social context in which the Romanian Orthodox population evolved for centuries was also the consequence of the imposition of several limitative measures regarding the building of long-lasting churches, made of stone. For this reason, the number of old stone churches is much lower than the number of wooden churches.

Taking age as reference, the oldest stone churches located in the analysed territory are „Saint Archangels Michael and Gabriel” in Borzești (Iara commune), built in the $18^{\text {th }}$ century, and the Unitarian Church in Iara village, built between the $13^{\text {th }}$ and $15^{\text {th }}$ centuries, and rebuilt in the $18^{\text {th }}$ century.
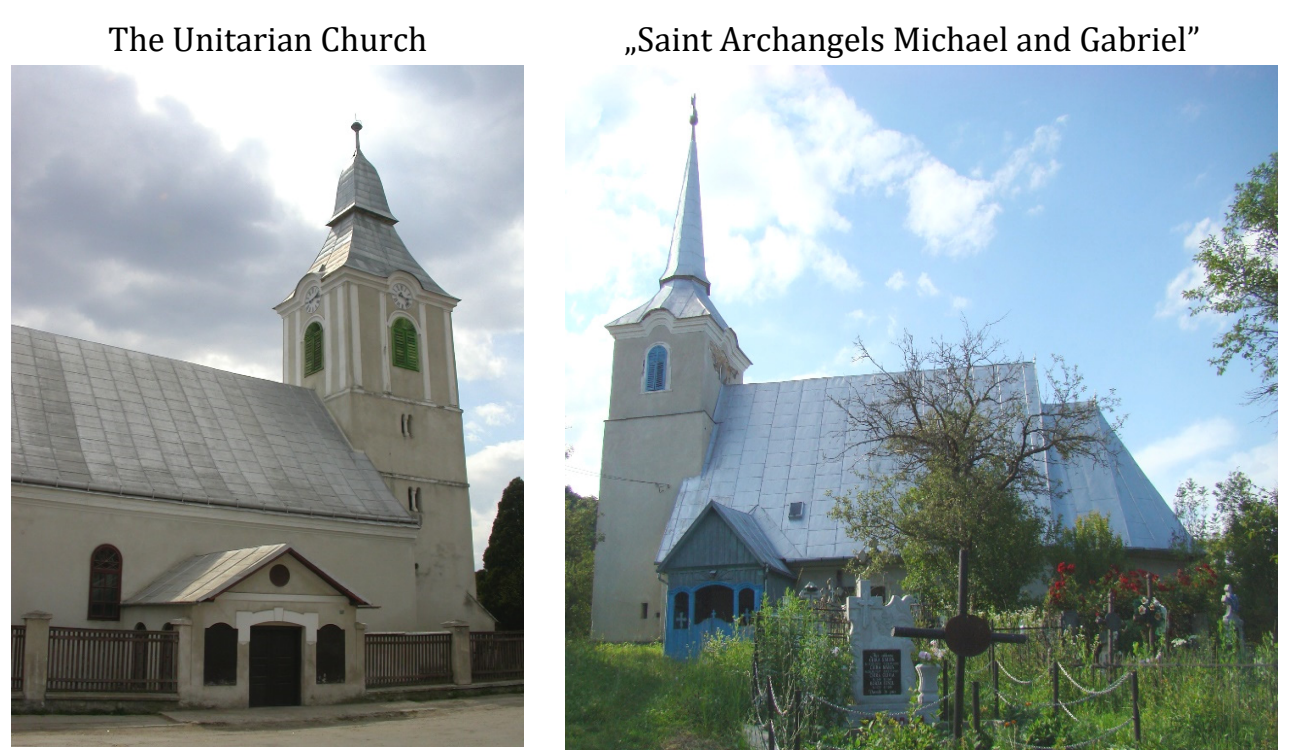

Fig. 3. The oldest stone churches in Iara-Hășdate basin

Starting with the end of the $18^{\text {th }}$ century and the beginning of the $19^{\text {th }}$ century, the building of stone churches is extended. Some of them were raised on the location of former wooden churches. Many stone churches built during this period took over several elements from the wooden churches, keeping the wooden tower and roof. The dissemination area of the religious buildings is therefore expanded to the entire region, each community having its own church. However, these churches are not integrated in the tourism circuit, either because they have been recently built or because they lack any notable attractions. 


\section{The attractive potential of monasteries}

Monasteries represent architectonic complexes having a high spiritual weight, centred around churches or cathedrals, where monastic communities and commoners link with the divinity.

After 1989 many new monasteries have been built, a fact doubled by the resettlement of other older monasteries, which did not function for political reasons during the communist period. The only monastery located in the study area is „Saint Prophet Elijah the Tishbite” in Băișoara, built after 1989. As with other monasteries which recently emerged in the cultural and religious landscape of the area, it still has a low impact on religious tourism.

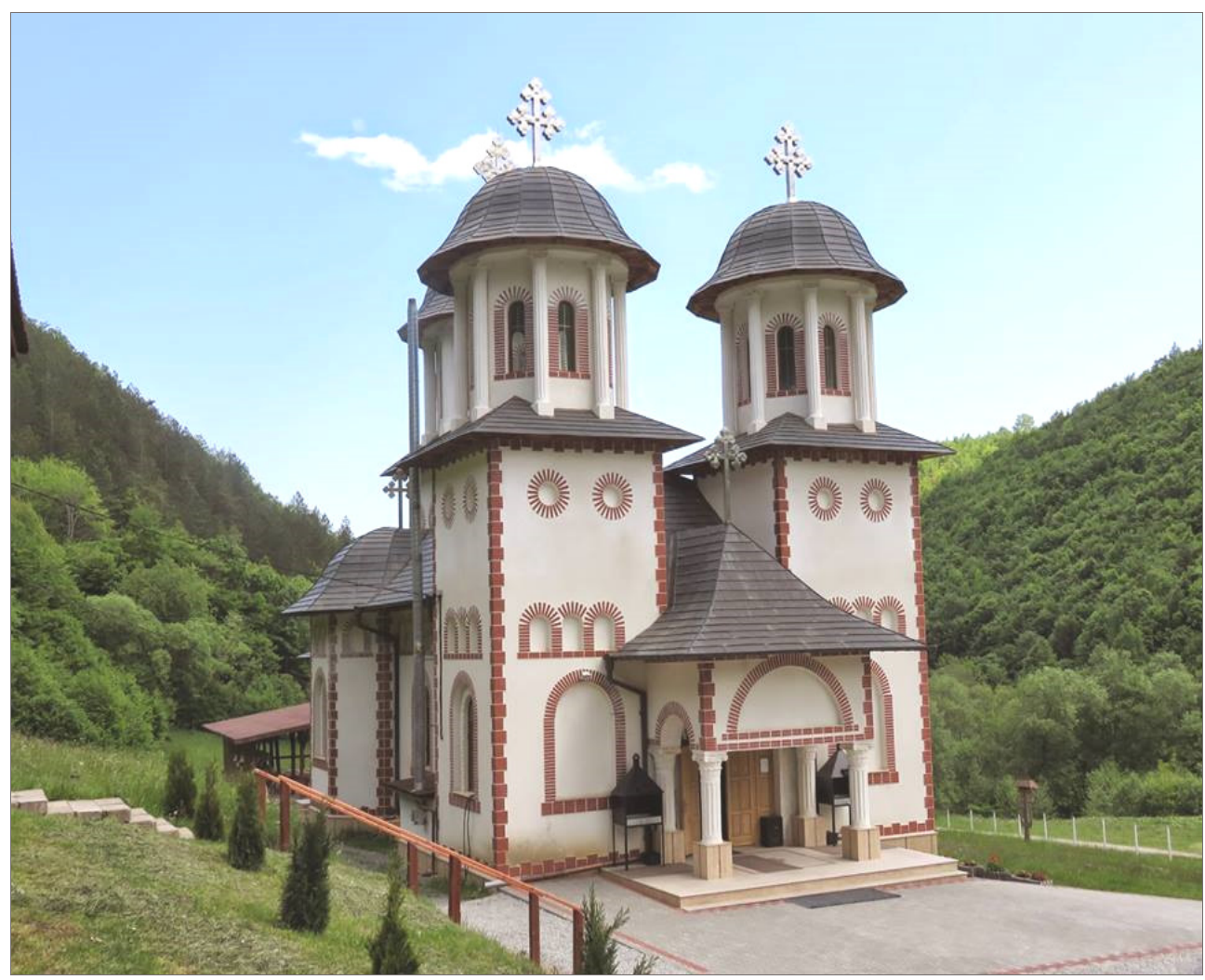

Fig. 4. „Saint Prophet Elijah the Tishbite” Monastery, Băișoara. 


\section{TYPES AND FORMS OF TOURISM}

The diversity and complexity of the tourism phenomenon revealed by the approach to identify, assess and evaluate the natural and the anthropogenic attractive resources highlight the study area as a space suitable for the practice of relative complex types of tourism. The presence and territorial location of the existing tourist attractions have a decisive impact on the types of tourism, such as recreational tourism, cultural tourism and mixed tourism, by means of which they are exploited and capitalized. This aspect is revealed by the high number of practiced and potential forms of tourism, induced and subsidized by the existing territorial attractions, either directly (by capitalizing a certain category of material or immaterial attractive resources) or indirectly (those forms which capitalize the esthetic or landscaping values of the natural environment and/or some of its features).

The presence, stored attractive values and territorial grouping of attractive elements are favorable premises that determine the emergence and practice of different forms of tourism. They also allow for the delineation of areas that have specialized or complex tourism functions, which may and should make the object of a policy to bring out the analyzed area within a development strategy as soon as possible.

There are many favourable premises for the practice of a varied range of types and forms of tourism: the presence of many natural and anthropogenic attractive resources, the accessibility given by the road network, the neighbouring location of Cluj-Napoca City - as a nodal tourist point to attract and disperse tourist flows in Cluj County and the entire North-West Region, the vicinity of Băișoara - Buscat Mountain area, the high accessibility provided by the marginal position of important European and national roads (E 60 and DN 75), as well as the A3 motorway, which crosses the study area. New types and forms of tourism may develop in the context of responsible spatial planning, as well as the needed modernization, diversification and functional adaptation. The abovementioned premises indicate the presence of a complex tourism profile and of areas with specialised or complex tourism functions, which are the object of a valorisation policy within the development strategy for the study area and for Cluj County as a whole in the medium and long term.

The study area is approached as a functional territorial system at the level of all its structural components, both within the study area as a distinct space and in its existing or possible relations to the neighbouring tourism systems, as an integral part of the functional county territorial system. Detailed analyses highlight types and forms of tourism that have an impact on the 
regional geographical and socio-cultural space, as well as a ranking configuration of the types and forms of tourism which may (and should) be promoted in this area in the future.

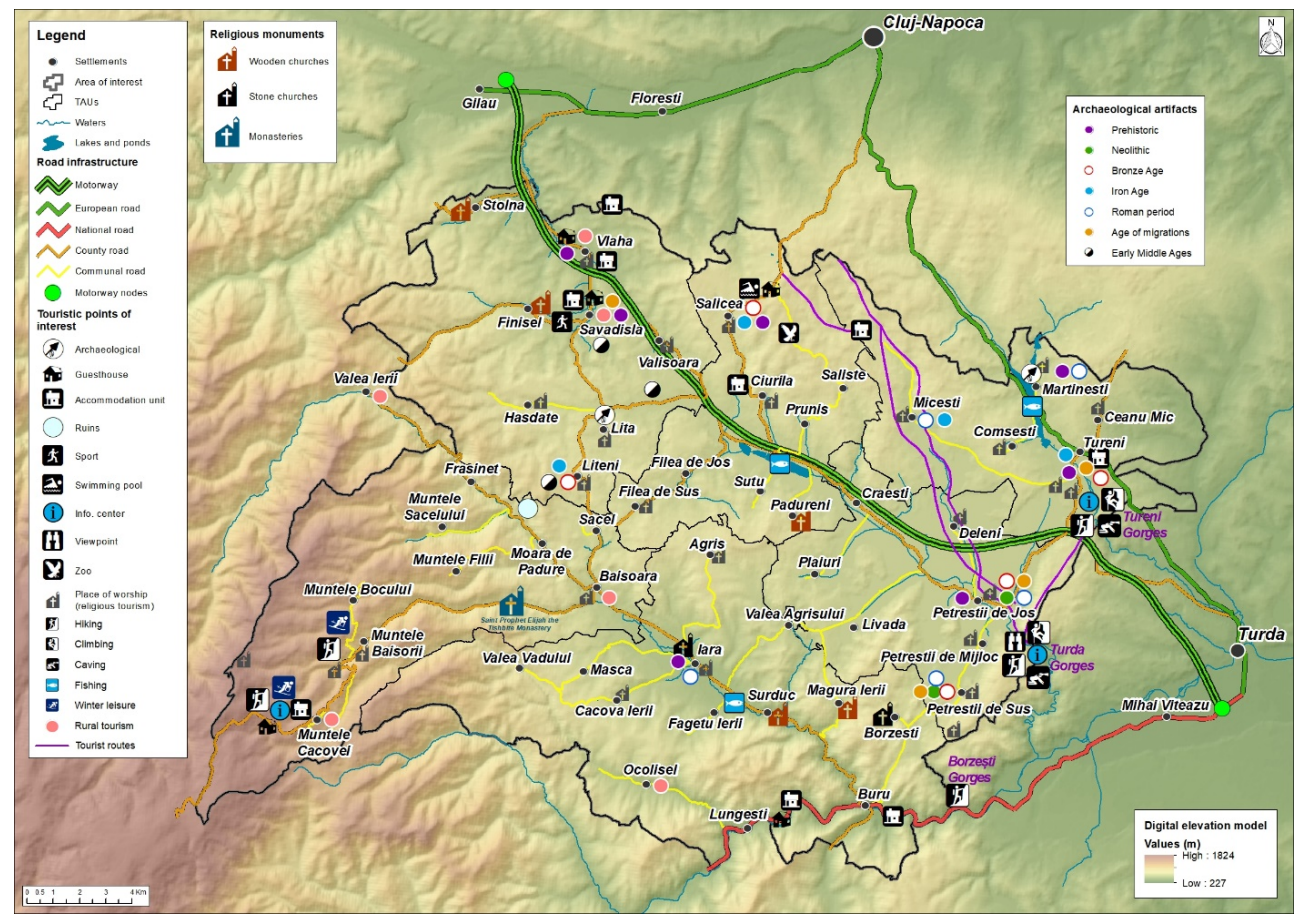

Fig. 5. Map of anthropogenic tourist resources in Iara-Hășdate basin

1. The recreational mountain tourism is on the top of the pyramid in terms of future opportunities due to a high attractive potential provided by the large area covered by mountains, characterized by a potentially valuable ski area, although not yet fully accounted for. The varied resources provide the opportunity for the practice of many forms of tourism, such as: speleotourism (caving), mountain climbing, hiking, hunting and fishing tourism, etc.

\section{- The winter leisure tourism (for winter sports -ski, bobsleigh, luge,} skating) has many opportunities for development and diversification in the mountain area, especially in Gilău-Muntele Mare Mountains where snow is present for five months annually above $1700 \mathrm{~m}$. However, there are few places planned in this respect, weakly diversified and of a modest quality. Băișoara and Buscat Mountain are the only locations which provide ski slopes with a 
medium degree of planning. There is need for the planning of other ski slopes (including routes for cross-country skiing), bobsleigh and luge, with different degrees of difficulty, as well as new skating rinks;

- Speleotourism (caving) is one of the most novel, interesting and profitable forms of tourism. To be practiced in optimal conditions, the caves included in the tourism circuits should be properly equipped and visits should be adequately planned. Nowadays, caving is practiced in an unorganised manner, economically inefficient and extremely negative regarding the conservation of the underground heritage. There are many underground cavities (caves and potholes) which may be arranged for tourism, especially the ones in the area of Turda Gorges and Tureni Gorges;

- Mountain climbing is another form of mountain recreational tourism which may be practiced in several mountain areas, such as Surduc Gorges, Ocolișel Gorges, but mainly in Turda Gorges and Tureni Gorges, where there are a number of routes with a high degree of difficulty (grades IV to VI in UIAA scale) but there are also easier climbs for initiation (grades II - III). However, routes should be properly signposted, climbing areas should be arranged adequately and accommodation units should be built for hosting the climbers;

- Hiking is mainly stimulated by the morphological and landscaping values of the mountain space, where the spectacular and morphologically varied landscape represents a major attractive resource. The high summits and long ridges of Muntele Mare and Gilău Mountains, the gorge and canyon sectors (Turda Gorges, Tureni Gorges, Arieș Canyon) represent areas of reference frequently visited by hikers. Despite the clear advantage of the mountain space in terms of hiking, the basin space itself may also provide areas for this activity. Most of the mountain trails have their starting point in villages located in the basin or at the contact between the mountains and the basin;

- Hunting tourism is favoured by the existence of remarkable game, especially in terms of large game (bear, deer, boar, wolf, fox, rabbit). It is organized and managed within hunting areas, more frequently located in the mountain ranges, such as Muntele Mare and Gilău Mountains, but also in the basins, where there is a higher degree of forest cover. These areas are also less affected by the presence of other human activities, especially forestry or mining, and therefore provide proper locations for the practice of this form of tourism, which also has a supplementary role in diversifying the supply of certain regions. In a perfectly controlled and rigorously organised setting, provided by a specialised accompanying staff, already trained in this direction, one may hunt exceptional specimens, while respecting and preserving the reproduction matrices at the level of each species. Hunting tourism is practiced by a low number of people, but usually having a high income, and therefore is an economically efficient activity; 
- Fishing tourism (sporting or leisure fishing) has proper conditions for development due to the existence of a dense and unpolluted drainage network. However, the low discharge has been strongly affected by the massive deforestation of the previous century, which even have had an accelerated pace during the last two decades. Deforestation have also had a negative impact on the fishing biological potential, which has decreased constantly. Fishing may be practiced along the main streams in the area (Arieș, Hășdate, Iara) and in the reservoirs (Bondureasa, Şoimului I and II etc);

- Extreme tourism (gliding with a paraglider or hang glider, motocross, mountain biking or cycling tourism, river rafting, etc.) may be practiced in favourable conditions in the mountains. Slopes, gradients, difference in height, terrain fragmentation, corroborated with the favourable dynamic elements such as air currents or water streams, may provide an adequate setting for the practice of such activities;

2. Cultural tourism is ranked highly among the forms of tourism that are practiced or may be practiced in the area, due to the high attractive potential provided by a diverse range of historical, religious, ethnographical, cultural and economic attractions.

In this study area, cultural tourism is mainly divided into two types in terms of practice: rural tourism and religious tourism.

- Rural tourism has a strong cultural background, as it tends to value the customs, traditions or local folklore, components of the rural civilisation still preserved in many of the villages, especially in the mountain area (Băişoara, Valea Ierii, Ocolișel, Muntele Cacovei, etc), but also in the basins (Vlaha and Săvădisla).

- Religious tourism takes into account the valorisation of the existing religious attractions and of the events organised by them (feast days, pilgrimages). This form of tourism is favoured by the existence of churches and monasteries. The most representative attraction of this type is the monastery at Băișoara, whose feast day is an event which annually attracts many visitors.

3. Mixed or polyvalent tourism results from the spatial association of two or more types of tourism in order to satisfy the needs of tourists in a fast and complex manner. There is a frequent association between leisure tourism and cultural tourism within rural tourism, which became a form of tourism that has an ever-increasing impact in the study area.

Other forms of tourism which may be practiced successfully in the study area include scientific tourism, festival and event-related tourism and transit tourism. 
- Specialised scientific tourism, including didactic and educational tourism and certain forms of leisure tourism, is favoured by the existence of natural areas or cultural attractions which have a certain scientific status, based on significant scientific or cultural values. Especially in summer, these attractions may represent focal points of a tourism demand motivated by their study for scientific or formative-educational purposes, by specialists or for the training of future specialists, researchers, students or pupils, in fields like history, archaeology (mainly in the archaeological sites disseminated across the study area) and ecotourism. The development of ecotourism supposes a certain awareness regarding ecology and a number of activities in nature, including the observation of floristic and faunistic aspects. This form of tourism is based on the protected nature reserves in the study area and its development contributes to the preservation of these protected areas, providing also a source of income for the local population.

- Festival and event-related tourism is a form of tourism based on the opportunities provided by different types of events, like cultural and artistic events, expos, fairs, folk dancing competitions, festivals or sporting events. They are present in more and more villages, and many of them are organised during the feast days of the village. To all these, one may add a large range of popular celebrations and festivals valuing the specific ethnographical resources of different areas.

- Transit tourism is favoured in its development by the location of important national and international roads in the northern (E 60 / DN 1) and southern (DN 75) parts of the study area. A 3 motorway also crosses the area from Turda to Gilău, but without any entries/exits. All these roads connect the area to the rest of Romania and other European countries, therefore facilitating transit to and from many locations. Cluj-Napoca International Airport also provides air connections to diverse domestic and foreign destinations, and the number of passengers is increasing every year.

\section{CONCLUSIONS}

The anthropogenic tourism resources of Iara-Hășdate area are the result of the combining effect of history, development of human civilization and typology and traditions of ethnic groups inhabiting the basin. The result is a unique cultural heritage belonging to both material and spiritual legacy, with visible attractive products for tourism materialized mostly in architecture, clothing, customs, music and gastronomy. Less visible, but very important, effects are 
noticed in the mentality of inhabitants and territorial arrangements of villages. Anthropogenic tourism resources are linked with the location and natural conditions of the studied area, the general environment being often the main factor for the appearance, evolution and development of some elements that today are extremely attractive resources for tourism.

The historical evolution of the area is reflected not only by culture, traditions and attitudes of the people towards lifetime events, but also by the relatively high number of tourism attractions from different historical periods, generating iconic architectural, historical and religious landmarks. In this context, Iara-Hăsdate Basin is characterized by a vast cultural and historical tourism heritage attested by the archaeological artifacts, result of the population's longstanding continuity and evolution. Churches and monastic sites, very present in the area, are valued not only as technical and artistic religious buildings, but are treasured for their symbolic value and their tourist reputation and attractiveness can be easily capitalized in each community.

Considering the complexity of tourism resources available in IaraHășdate Basin, there are multiple types and forms of tourism offered by the area. Existing natural conditions favor various forms of recreational mountain tourism from traditional winter leisure tourism, hiking and hunting tourism to more extreme ones like mountain climbing, speleotourism and extreme tourism. The rich historical cultural heritage of the studied area offers very good premises for the development of various cultural tourism forms, mostly rural and religious tourism. Given the combination of both natural and anthropogenic tourism resources, advantages of location and general needs of tourists, IaraHășdate Basin has favorable conditions for different other forms of mixed and polyvalent tourism, including, but not limited to, scientific tourism, transit tourism, and festival or event-related tourism.

The results of tourism resources assessment can be used to coordinate tourism development strategies for a superior endorsement and to better prioritize tourism related policies with a focus on economic development, land use management, territorial identity and environmental quality.

\section{REFERENCES}

1. Bodea, V. (2009), Hăssdate: studiu monografic, Edit. Arcadia Media, Cluj-Napoca.

2. Buta, I., Idu, P.D., Edroiu, N. (1980), Cluj. Ghid turistic al judeţului, Edit. SportTurism, Bucharest.

3. Cândea, Melinda and Simon, Tamara (2006), Potenţialul turistic al României, Edit. Universitară, Bucharest. 
4. Cazes, G. (1992), Fondements pour une géographie du tourisme et des loisirs, Edit. Bréal, Paris.

5. Ciangă, N. (1997), Turismul în Carpaţii Orientali: Studiu de geografie umană, Edit. Presa Universitară Clujeană, Cluj-Napoca.

6. Ciangă, N. (2007), România. Geografia turismului, Edit. Presa Universitară Clujeană, Cluj-Napoca.

7. Cinezan, V. (2011), Ciurila - microunivers transilvan, Edit. Eikon, Cluj-Napoca.

8. Cocean, P. (1996), Geografia turismului, Edit. Caroo, Bucharest.

9. Cocean, P., Dezsi, Şt. (2005), Prospectare şi geoinformare turistică, Edit. Presa Universitară Clujeană, $2^{\text {nd }}$ revised edition, Cluj-Napoca.

10. Cocean, P., Dezsi, Şt. (2009), Geografia turismului, Edit. Presa Universitară Clujeană, Cluj-Napoca.

11. Consiliul Județean Cluj, Harta Digitală a Judeţului Cluj, available at http://www.cjcluj.ro/, last accessed on: 27 February 2019.

12. Consiliul Județean Cluj, Județul Cluj, available at http://www.cjcluj.ro/judet/, last accessed on: 27 February 2019.

13. Copilu Cheatra, V. (1989), Iara, Edit. Dacia, Cluj-Napoca.

14. Dezsi, Şt. (2006), Patrimoniu şi valorificare turistică, Edit. Presa Universitară Clujeană, Cluj-Napoca.

15. Enciclopedia României, Portul popular din Transilvania, available at: http://enciclopediaromaniei.ro/wiki/Portul_popular_din_Transilvania, last accessed on 27 February 2019.

16. Gergely, E. (2002), Tureni: studio monografic, Edit. Casa Cărții de Ştiință, ClujNapoca.

17. Gergely, E., Luca E. (2004), Iara: studio monografic, Edit. Casa Cărţii de Ştiinţă, Cluj-Napoca.

18. Ghinoiu, I. (2003a), Atlasul etnografic român, Volumul I: Habitatul, Institutul de Etnografie şi Folclor „Constantin Brăiloiu”, Edit. Academiei Române, Bucharest.

19. Ghinoiu, I. (2003b), Sărbători şi obiceiuri. Vol. III: Transilvania, Edit. Enciclopedică, Bucharest.

20. Ghinoiu, I. (2005a), Atlasul etnografic român, Volumul II: Ocupaţiile, Institutul de Etnografie și Folclor „Constantin Brăiloiu”, Edit. Academiei Române, Bucharest.

21. Ghinoiu, I. (2005b), Comoara satelor: calendar popular, Edit. Academiei Române, Bucharest.

22. Ghinoiu, I. (2011), Atlasul etnografic român, Volumul IV: Portul şi arta populară, Institutul de Etnografie şi Folclor „Constantin Brăiloiu”, Edit. Academiei Române, Bucharest.

23. Glăvan, V. (2000), Turismul în România, Edit. Economică, Bucharest.

24. Ielenicz, M., Comănescu, Laura (2013), Turism, teorie şi metodologie, Edit. Universitară, Bucharest.

25. Institutul de Memorie Culturală, Lăcaşuri de cult din România - Baza de date online, available at http://www.cimec.ro/Monumente/LacaseCult/default_ro.htm, last accessed on: 27 February 2019. 
26. Institutul Naţional al Patrimoniului, Lista Monumentelor Istorice 2015. Judeţul Cluj, Anexă la Ordinul Ministrului Culturii nr. 2.828/2015, pentru modificarea anexei nr. 1 la Ordinul Ministrului Culturii şi Cultelor nr. 2.314/2004 privind aprobarea Listei monumentelor istorice, actualizată, şi a Listei monumentelor istorice dispărute, cu modificările ulterioare din 24.12.2015, Ordin publicat în Monitorul Oficial al României, Partea I, Nr. 113 bis, 15.02.2016, available at http://patrimoniu.gov.ro/ro/, last accessed on: 27 February, 2020.

27. Lăzărescu, L. (2006), Mărtineşti, vechiul meu sat transilvan, Edit. Polidava, Deva.

28. Luca, Minodora Susana (2007), Băişoara - locul sufletului nostru, Edit. Casa Cărţii de Ştiinţă, Cluj- Napoca.

29. Mac, I. (1992), Geografie turistică generală, Universitatea Independentă Dimitrie Cantemir, Sibiu.

30. Minciu, Rodica (2004), Economia turismului, $3^{\text {rd }}$ edition, revised and completed, Edit. Uranus, Bucharest.

31. Mititean, R., Kadar, A. (1996), Zona turistică Băişoara şi masivul Muntele Mare: ghid turistic, Edit. Fundaţia Soros pentru o Societate Deschisă, Bucharest.

32. Moldovan, C, Dezsi, Şt., Rusu, R., Man, T., Dolean, E.B. (2017), The natural environment and tourism potential of Iara-Hăşdate Basin, Studia Universitatis Babeș-Bolyai, Geographia, Vol, 62, No. 1, pp. 105-124.

33. Morariu, T., Savu, Al. (1970), Judeţul Cluj, Edit. Academiei Republicii Socialiste România, Bucharest.

34. Muntele, I., Iaţu, C. (2003), Geografia turismului: concepte, metode şi forme de manifestare spaţio-temporală, Edit. Sedcom Libris, Iaşi.

35. Negucioiu, A., Teodor, P., Edroiu, N. (1980), Cluj. Județele Patriei. Monografie, Edit. Sport- Turism, Bucharest.

36. Neguț, S. (2003), Geografia turismului, Edit. Meteor Press, Bucharest.

37. Pop, Gr.P. (2007), Judeţul Cluj - Judeţele României, Edit. Academiei Române, Bucharest.

38. Pop, I.A., Danciu, M. I., Cocean, P., Luţaş, Mihaela (2008), Judeţul Cluj, Consiliul Județean Cluj, Edit. Tribuna, Cluj-Napoca.

39. Pop, I.A., Porumb, M., coord. (2006), Patrimoniul natural şi cultural al României: Munţii Apuseni, Institutul Cultural Român, Centrul de Studii Transilvane, ClujNapoca.

40. Răcăşan, Bianca Sorina (2014), Types and forms of tourism based on natural and anthropic tourist resources in Apuseni Mountains. Case study: Rural Mountain Area of Cluj County, Geographica Timisiensis, Vol. XXIII, No. 2, pp. 5-26.

41. Răcăşan, Bianca Sorina (2015), Prospecting Event Tourism within the RuralMountain Area of Cluj County by means of Online Promotion, Journal of Settlements and Spatial Planning, Special Issue, No. 4, pp. 199-209.

42. Răcăşan, Bianca Sorina, Potra, Alexandra Camelia, Găman, G. (2016), Tourism Potential Value Assessment Model for Rural-Mountain and Boundary Contact Areas. Case Study: Cluj County, The District of Ciceu and the Balneary Area of Bacău County (Romania), Journal of Environmental and Tourism Analyses, Vol. 4, No. 1, pp. 74-96. 
43. Snak, O. (1976), Economia şi organizarea turismului, Edit. Sport-Turism, Bucharest.

44. Surd, V. (2013), Miceşti (Micuş) un sat transilvănean, Edit. Presa Universitară Clujeană, Cluj-Napoca.

45. Vana, C. (2003), Cacova Ierii: studiu monografic, Edit. Boema, Turda.

46. Vișinescu, V., Bujor, Mariana (2013), Petreștii de Jos: un colţ de ţară românească: Vatra folclorică şi spaţiul păstrării fiinţei naţionale, Edit. Casa Cărţii de Ştiinţă, Cluj-Napoca.

47. Vişinescu, V., Lechinţan, V. (2002), Petreştii de Jos: studiu monografic, Edit. Casa Cărţii de Ştiinţă, Cluj-Napoca.

48. *** (2005), Planul de Dezvoltare a Judeţului Cluj. Studiu sectorial-Turismul. Proiect nr. 12899/2005, Academia Română- Filiala Cluj. Colectivul de Geografie, ClujNapoca.

49. ** (2011), Strategia de Dezvoltare a Județlui Cluj pentru perioada 2014-2020, document written during the project „Elaborarea Strategiei de Dezvoltare a Judeţului Cluj pentru perioada 2014-2020”, Code SMIS 12836, financed from the European Social Fund, by means of Operational Programme Administrative Capacity Development; beneficiary: Cluj County Council. 